\title{
Strategi Tata Kelola BUMDes dalam Upaya Menunjang Ekonomi Masyarakat Di Desa Pamulihan Kecamatan Cisurupan Kabupaten Garut
}

\author{
Ayi Sofian 1 \\ ${ }^{1}$ Magister Administrasi Publik, Pascasarjana Universitas Sultan Ageng Tirtayasa \\ Jalan Raya Jakarta Km 4 Pakupatan Kota Serang Provinsi Banten 42121
}

\begin{abstract}
Village-Owned Enterprises (BUMDes) is a village economic institution that aims to help support driving the economy of rural communities. Pamulihan Village, where the majority of the people were farmers, really needed BUMDes in order to support and improve the village economy. The research objective was to analyze the level of participation of the Pamulihan Village Community in the existence of BUMDes in order to support village economic development. This research is a type of qualitative research with data collection techniques in the form of interviews and documentation. The results showed that 1) BUMDes Pamulihan Village had succeeded in giving a positive impact on improving the village economy and community welfare. 2) Management of BUMDES by the management is very orderly based on the regulations that have been set by the government, 3) BUMDES Pamulihan Village although not maximized in running its business units, based on the data collected, it was found that high community participation in welcoming the existence of BUMDes
\end{abstract}

Keywords: BUMDes, Pamulihan Village, Community, Participation and Economy.

\section{Pendahuluan}

Desa merupakan unit terkecil dari negara yang merupakan pemerintahan terdekat dengan masyarakat, Desa secara riil menyentuh kebutuhan dan pelayanan kepada masyarakat dengan tujuan mensejahterakan. Menurut Undang-Undang Desa (UU Nomor 6 Tahun 2014) Desa adalah kesatuan masyarakat hukum yang memiliki batas wilayah, yang berwenang untuk mengatur dan mengurus urusan pemerintahan, kepentingan masyarakat setempat berdasarkan prakarsa masyarakat, hak asal usul, dan/atau hak tradisional yang diakui dan dihormati dalam sistem pemerintahan Negara Kesatuan Republik Indonesia (NKRI). Sebagai wakil negara, desa wajib melakukan pembangunan baik pembangunan fisik maupun pembanguan sumber daya manusia, sebagai upaya peningkatan kualitas hidup dan kehidupan untuk sebesarbesarnya kesejahteraan masyarakat desa.

Pertumbuhan ekonomi desa seringkali dinilai lambat dibandingkan pembangunan ekonomi perkotaan. Untuk meningkatkan hal 
tesebut dibutuhkan dua pendekatan yaitu: a) Kebutuhan masyarakat dalam melakukan upaya perubahan dan mencegah hal-hal yang tidak diinginkan, dan b) Political will dan kemampuan pemerintah desa bersama masyarakat dalam mengimplementasikan perencanaan pembangunan yang sudah disusun.(Tokan, 2016)

Pembangunan pada hakekatnya bertujuan membangun kemandirian,termasuk pembangunan pedesaan. Salah satu misi pemerintah adalah membangun daerah pedesaan yang dapat dicapai melalui pemberdayaan masyarakat untuk meningkatkan produktivitas dan keanekaragaman usaha pedesaan. Membangun dan memperkuat institusi yang mendukung rantai produksi dan pemasaran, serta mengoptimalkan sumber daya sebagai dasar pertumbuhan ekonomi pedesaan. Tujuannya, adalah untuk memberi peluang bagi kemampuan daerah dan pedesaan sebagai tulang punggung ekonomi regional dan nasional.

Kemajuan ekonomi nasional hanya akan tercapai jika terdapat iklim perekonomian yang baik di tingkat provinsi. Kemajuan ekonomi di tingkat provinsi akan tercapai jika perkonomiankabupaten berjalan baik. Kemajuan ekonomi sebuah kabupaten dapat tercapai karena adanya sumbang dari ekonomi pedesaan yang kuat berimbas pada kesejahteraan masyarakat luas. Hal ini akan menjamin penyelenggaraan pemerintahan yang baik untuk diterapkan di semua tingkat pembangunan dan keputusan berdasarkan kebutuhan nyata dari masyarakat.

Pembangunan pedesaan merupakan salah satu cara dalam upaya mengentaskan kemiskinan di Indonesia. Pengembangan basis ekonomi di pedesaan sudah semenjak lama dijalankan oleh pemerintah melalui berbagai program. Namun upaya itu belum memuaskan sebagaimana diinginkan bersama. Salah satu faktor yang paling dominan adalah intervensi pemerintah terlalu besar, akibatnya justru menghambat daya kreativitas dan inovasi masyarakat desa dalam mengelola dan menjalankan mesin ekonomi di pedesaan. Sistem dan mekanisme kelembagaan ekonomi di pedesaan tidak berjalan efektif dan berimplikasi pada ketergantungan terhadap bantuan pemerintah sehingga mematikan semangat kemandirian.

Berdasarkan asumsi itulah maka sudah seharusnya eksistensi desa mendapatkan perhatian yang serius dari pemerintah pusat dengan lahirnya kebijakankebijakan terkait dengan pemberdayaan ekonomi yang dilakukan dengan cara menghimpun dan melembagakan kegiatan ekonomi masyarakat. Oleh karena itu pemerintah menerapkan pendekatan baru yang diharapkan mampu menstimulus dan menggerakkan roda perekonomian di pedesaan adalah melalui pendirian kelembagaan ekonomi yang dikelola sepenuhnya oleh masyarakat desa yaitu Badan Usaha Milik Desa (BUMDes) sebagai salah satu program andalan dalam meningkatkan kemandirian perekonomian desa.

\section{Metode Penelitian}

Penelitian ini dilaksanakan di Desa Pamulihan, Kecamatan Cisurupan, Kabupaten Garut. 
Pemilihan lokasi dilakukan dengan pertimbangan karena Desa Pamulihan adalah desa yang mempunyai potensi untuk dikembangkan usaha dan jenis mata pencaharaian masyarakatnya. Selain desa ini jarang terjamah oleh kalangan akademisi yang meneliti, sehingga diharapkan dapat memberi sumbangan pemikiran terhadap pengelolaan BUMDes dari perspektif kajian ilmiah guna peningkatan ekonomi masyarakat Desa Pamulihan. Penelitian ini dilakukan selama 3 bulan (September 2020-Januari 2021).

Kami selaku penulis bermotivasi untuk melakukan penelitian di Desa Pamulihan dengan menggunakan metode penelitian kualitatif dengan teknik pengumpulan data berupa wawancara dan dokumentasi, dimana metode penelitian kualitatif merupakan penelitian tentang riset yang bersifat deskriptif dan cenderung menggunakan analisis, sehingga desa ini menurut kami sangat bagus untuk kami teliti dan mengetahui informasinya. Sedangkan data kualitatif didapat melalui wawancara dengan menggunakan interview kepada beberapa informan.

Populasi pada penelitian ini adalah seluruh pengurus/pengelola BUMDes yang memiliki usia antara 18-65 tahun, yang berjumlah 13 orang, kepala Desa 1 orang, tokoh masyarakat dan tokoh pemuda 17 orang dan pegawai desa 7 orang. Unit analisis dalam penelitian ini adalah individu. Informan dalam penelitian ini terdiri orang-orang yang mengetahui keterlibatan masyarakat desa dalam BUMDes Desa Pamulihan, diantaranya adalah ketua BUMDes Desa Pamulihan, staf bagian administrasi, manajer dan koordinator lapangan dari beberapa usaha yang ada pada BUMDes Desa Pamulihan.

\section{Hasil dan Pembahasan \\ 1. Konsep Desa}

Pengertian Desa secara umum lebih sering dikaitkan dengan pertanian. Misalnya, (Amri, 2019) mendefinisikan desa sebagai "setiap pemukiman para petani (peasants)". Sebenarnya, faktor pertanian bukanlah ciri yang harus melekat pada setiap desa. Ciri utama yang terlekat pada setiap desa adalah fungsinya sebagai tempat tinggal (menetap) dari suatu kelompok masyarakat yang relatif kecil. Landis (eprints.uny.ac.id) terdapat tiga definisi tentang desa yaitu pertama desa itu lingkungan yang penduduknya kurang dari 2.500 orang, kedua desa adalah suatu lingkungan yang penduduknya mempunyai hubungan yang saling akrab serba informal satu sama lain, dan yang ketiga desa adalah suatu lingkungan yang penduduknya hidup dari pertanian

Menurut UU No. 6 tahun 2014 Tentang Desa, pasal 1 ayat 1 , menjelaskan bahwa Desa adalah desa dan desa adat atau yang disebut dengan nama lain, selanjutnya disebut Desa, adalah kesatuan masyarakat hukum yang memiliki batas wilayah yang berwenang untuk mengatur dan mengurus urusan pemerintahan kepentingan masyarakat setempat berdasarkan prakarsa masyarakat, hak asal usul, dan/atau hak tradisional yang diakui dan dihormati dalam sistem pemerintahan Negara Kesatuan Republik Indonesia (NKRI).

(Faedlulloh, 2018) menjelaskan desa ialah "suatu hasil perpaduan antara kegiatan sekelompok manusia dengan lingkungannya. Hasil dari 
perpaduan itu ialah suatu wujud atau kenampakan di muka bumi yang ditimbulkan oleh unsur- unsur fisiografi, sosial, ekonomi, politik dan cultural yang saling berinteraksi antar unsur tersebut dan juga dalam hubungannya dengan daerah-daerah lain". Sementara itu dalam media UNAND pengertian desa menurut Koentjaraningrat (1977) ialah melalui pemilahan pengertian komunitas dalam dua jenis, yaitu komunitas besar (seperti: kota, negara bagian, negara) dan komunitas kecil (seperti: dusun, desa, rukun tetangga dan sebagainya). Dalam hal ini Koentjaraningrat mendefinisikan desa sebagai "komunitas kecil yang menetap tetap di suatu tempat" (1977:162). Koentjaraningrat tidak memberikan penegasan bahwa komunitas desa secara khusus tergantung pada sektor pertanian. Dengan kata lain artinya bahwa masyarakat desa sebagai sebuah komunitas kecil itu dapat saja memiliki ciri-ciri aktivitas ekonomi yang beragam, tidak di sektor pertanian saja.

Selanjutnya,

Selanjutn

(Widiastuti et al., 2019) seorang sarjana sosiologi perdesaan dari Amerika Serikat, mengemukakan definisi tentang desa dengan cara membuat tiga pemilahan berdasarkan pada tujuan analisis. Untuk tujuan analisis statistik, desa didefinisikan sebagai suatu lingkungan yang penduduknya kurang dari 2500 orang. Untuk tujuan analisa sosialpsikologi, desa didefinisikan sebagai suatu lingkungan yang penduduknya memiliki hubungan yang akrab dan serba informal di antara sesama warganya. Sedangkan untuk tujuan analisa ekonomi, desa didefinisikan sebagai suatu lingkungan yang penduduknya tergantung kepada pertanian (fisip.unand.ac.id, 2013). Jurnal Istiqro: Jurnal Hukum Islam, Ekonomi dan Bisnis Vol.5 / No.1: 101113, Januari 2019 ISSN : 2599-3348 (online) ISSN : 2460-0083 (cetak) 104 Dengan demikian penegertian desa jelas memberi gambaran suatu kelompok manusia atau masyarakat yang aktivitasnya berkaitan dengan elemen lingkungan alam atau lingkungan fisik maupun sosial kemasyarakatan, dan memiliki komunikasi dengan daerah lain, secara lancar dan terbuka dan kurang lancar atau terisolir dari dan dengan daerah lain.

Ciri-Ciri Perekonomian Desa Menurut kompasiana ciri yang menonjol pada masyarakat pedesaan yaitu ; 1.) Kehidupan didesa masyarakatnya masih memegang teguh keagamaan atau adat dari leluhur mereka. 2.) Warga pedesaan lebih condong saling tolongmenolong tidak hidup individualism 3.) Warga pedesaan mayoritas memiliki pekerjaan sebagai petani. 4.) Fasilitas-fasilitas masih sulit ditemukan dipedesaan. 5.) Warganya masih sulit untuk menerima hal baru atau mereka tertutup dengan hal-hal yang baru.

\section{BUMDes dalam Perspektif Undang - Undang Desa}

Undang-Undang desa mengamahkan dalam pasal 87 bahwa pemerintah desa dapat mendirikan BUMDes; BUMDes harus dibangun dengan semangat kekeluargaan dan kegotong royongan serta menjalankan usaha di bidang ekonomi atau pelayanan umum untuk kesejahteraan bagi masyarakat desa. BUMDes dibentuk melalui musyawarah desa sebagai bahan pengkajian dan pengambilan keputusan terhadap hal yang 
dianggap penting dan strategis dalam penyelenggaraan pemerintahan desa sesuai dengan pasal 54 ayat (2a) dan pasal 88 ayat (1).

BUMDes merupakan elemen dan instrument penggerak ekonomi masyarakat desa. BUMDes harus dipahami dan dilakukan secara maksimal. BUMDes menjadi pusat perekonomian masyarakat desa untuk menumbuh kembangkan ekonomi lokal. Keberadaan BUMDes adalah untuk memperkuat ekonomi rakyat desa. (Widiastuti et al., 2019) BUMDes menjadi hak desa untuk memanfaatkan aturan UU Desa yang memberikan kewenangan kepada pemerintah desa untuk melakukan inovasi dalam pembangunan desa, terutama dalam hal peningkatan perekonomian desa dan kesejahteraan bagi masyarakat desa. BUMDes diharapkan menjadi motor penggerak ekonomi desa masyarakat yang dikelola secara baik dan professional. Keberadaan BUMDes menjadi harapan masyarakat desa untuk meningkatkan ekonomi desa melalui pengelolaan keuangan desa yang di dasarkan pada Anggaran Pembangunan dan Belanja Desa (APBDes).

Kawasan Perdesaan memiliki peran yang penting dalam mendukung pembangunan nasional. Kemandirian pembangunan kawasan pedesaan merupakan salah satu pendekatan dalam pembangunan kawasan perdesaan dalam mendorong perkembangan ekonomi di kawasan desa dengan memanfaatkan potensi yang ada di wilayah tersebut. Perkembangan Ekonomi kawasan perdesaan diharapkan dapat mengurangi ketergantungan kawasan pedesaan terhadap kota, dan menguatkan peran desa sebagai pusat produksi dan kebutuhan sumberdaya

pembangunan.

Membangun

hubungan keterkaitan antar desa-kota juga merupakan salah satu cara yang ditempuh sebagai suatu upaya pembangunan wilayah perdesaan, dimana peran desa dikuatkan sebagai pusat produksi dan sumberdaya. Keterkaitan tersebut dapat mengurangi ketergantungan kawasan perdesaan terhadap kawasan perkotaan, dan mengurangi angka urban masyarakat dari desa ke kota. Diharapkan pola tersebut mendorong perkembangan ekonomi desa dan mendorong permerataan ekonomi antara desa dan kota. Dalam hubungan yang lebih intensif, hubungan desa-kota tersebut dapat berupa interaksi spasial antar subsistem rantai agribisnis/agroindustri ((Tanjung, 2013), Perkembangan Ekonomi Kawasan Perdesaan).

Kawasan Perdesaan memiliki peran yang penting dalam mendukung pembangunan nasional. Kemandirian pembangunan kawasan pedesaan merupakan salah satu pendekatan dalam pembangunan kawasan perdesaan dalam mendorong perkembangan ekonomi di kawasan desa dengan memanfaatkan potensi yang ada di wilayah tersebut. Perkembangan Ekonomi kawasan perdesaan diharapkan dapat mengurangi ketergantungan kawasan pedesaan terhadap kota, dan menguatkan peran desa sebagai pusat produksi dan kebutuhan sumberdaya pembangunan. Membangun hubungan keterkaitan antar desakota juga merupakan salah satu cara yang ditempuh sebagai suatu upaya pembangunan wilayah perdesaan, dimana peran desa dikuatkan sebagai 
pusat produksi dan sumberdaya. Keterkaitan tersebut dapat mengurangi ketergantungan kawasan perdesaan terhadapkawasan perkotaan, dan mengurangi angka urban masyarakat dari desa ke kota.

Diharapkan pola tersebut mendorong perkembangan ekonomi desa dan mendorong permerataan ekonomi antara desa dan kota. Dalam hubungan yang lebih intensif, hubungan desa-kota tersebut dapat berupa interaksi spasial antar subsistem rantai agribisnis/agroindustri (Amri, 2019).

\section{Gambar 1}

Eksisting Penelitian

Kondisi masyarakat sebelum adanya BUMDES

Latar Belakang dan

Perencanaan pembentukan BUMDES

Kondisi masyarakat setelah adanya BUMDES

Dampak yang dirasakan oleh masyarakat

Sumber : Peneliti, 2021

\section{Gambaran \\ Umum \\ Desa Pamulihan}

Desa Pamulihan secara geografis berbatasan : sebelah utara dengan Desa Situsari, sebelah selatan dengan Desa Pangauban Timur, sebelah Barat dengan Kehutanan SDA Gunung Candra dan Kab.Bandung dan Sebelah timur dengan Desa Simpang Sari Barat. Desa Pamulihan berpenduduk 5.596 jiwa, terdiri dari 2.855 laki-laki dan 2.741 perempuan. Masyarakatnya bermata pencaharian mayoritas bertani dan berdagang, mempunyai Badan Usaha Milik Desa (BUMDes) dengan unit usaha yang pokok adalah penjualan pupuk kompos, pupuk kimia UREA ZA/TSP, pembibitan dan insektisida pembasmi hama tanaman.

BUMDes Desa Pamulihan didirikan tahun 2019 oleh tokoh masyarakat dan tokoh pemuda dengan di prakarsai BPDes, Kepala Desa dan Aparatur pegawai desa, meskipun dalam kepengurusan BUMDes tidak ada satupun aparatur Desa Pamulihan yang menjadi pengurus BUMDes karean tidak diperbolehkan UU dan atau Peraturan BUMDes. Pembentukan BUMDES di Desa Pamulihan ini memiliki tujuan utama yaitu sebagai upaya menunjang ekonomi masyarakat serta untuk meningkatkan taraf hidup masyarakat miskin agar kesenjangan sosial di desa ini tidak bertambah besar, karena menurut survei yang telah dilakukan Th. 2017 bahwa masih banyak jumlah KK di desa ini yang termasuk kategori masyarakat miskin yaitu sebanyak 223 KK dari total keseluruhan masyarakat Desa Pamulihan yang berjumlah 1.399 KK. Upaya untuk mencapai tujuan tersebut banyak sekali hal yang telah dilakukan oleh pemerintah Desa Pamulihan, salah satunya adalah dengan memberangkatkan sebagian tokoh masyarakat dan tokoh pemuda untuk pelantikan-pelatihan pengelolaan BUMDes dan pelatihan keterampilan peningkatan hasil produksi pertanian yang dibiayai dari swadaya dan dana sosial desa.

BUMDes D e s a P m ulihan lahir sebagai suatu pendekatan baru dalam usaha peningkatan ekonomi desa berdasarkan kebutuhan dan potensi desa. Pengelolaan BUMDes sepenuhnya dilaksanakan oleh masyarakat desa, yaitu dari masyarakat desa, oleh masyarakat desa, dan untuk masyarakat desa. Cara 
Kerja BUMDes adalah dengan jalan menampung kegiatan-kegiatan ekonomi masyarakat dalam sebuah bentuk kelembagaan atau badan usaha yang dikelola secara professional, namun tetap bersandar pada potensi asli desa. Hal ini dapat menjadikan usaha masyarakat lebih produktif dan efektif. Kedepan BUMDes akan berfungsi sebagai pilar kemandirian bangsa yang sekaligus menjadi lembaga yang menampung kegiatan ekonomi masyarakat yang berkembang menurut ciri khas desa dalam rangka meningkatkan kesejahteraan masyarakat desa. Adapun salah satu desa yang termasuk dalam ciri khas BUMDes tersebut adalah Desa Pamulihan Kecamatan Cisurupan Kabupaten Garut, ini merupakan desa yang sudah memiliki BUMDes yang telah berdiri sejak tahun 2019.

\section{Pendirian dan Pengelolaan Badan Usaha Milik Desa (BUMDES) secara Umum}

Pembentukan Badan Usaha Milik Desa (BUMDES) bertujuan sebagai lokomotif pembangunan ekonomi lokal tingkat desa. Pembangunan ekonomi lokal desa ini didasarkan oleh kebutuhan, ptotensi, kapasitas desa, dan penyertaan modal dari pemerintah desa dalam bentuk pembiayaan dan kekayaan desa dengan tujuan akhirnya adalah meningkatkan taraf ekonomi mayarakat desa. Dasar pembentukan BUMDes sebagai lokomotif pembangunan di desa lebih dilatarbelakangi pada prakarsa pemerintah dan masyarakat desa dengan berdasarkan pada prinsip kooperatif, partisipatif, dan emansipatif dari masyarakat desa.

Di dalam Buku Panduan
BUMDes yang diterbitkan oleh kementerian Pendidikan Nasional tahun 2007 dijelaskan secara terperinci bahwa ada beberapa tahapan dalam proses pendirian BUMDes. Selain itu juga dijelaskan mengenai cara dan syarat pendirian BUMDes yang terdiri atas: 1.) Pendirian BUMDES berdasar pada Perda Kabupaten. 2.) Diatur berdasarkan Perdes. 3.) Satu desa, hanya terdapat satu BUMDes 4.) Pemkab memfasilitasi pendirian BUMDes. 5.) BUMDes dapat didirikan dalam bentuk Usaha Bersama atau bentuk lainnya, tetapi bukan Koperasi, CV, UD, atau lembaga keuangan (BPR).

Dalam peraturan Menteri Desa No. 4/2015 pasal 5 juga menjelaskan mengenai proses pendirian BUMDes yang berbunyi "Pendirian BUMDES sebagaiman dimaksud dalam pasal 4 disepakati melalui Musyawarah Desa, sebagaimana diatur dalam peraturan Menteri Desa, Pembangunan Daerah Tertinggal, dan Transmigrasi tentang Pedoman Tata tertib dan Mekanisme Pengambilan Keputusan Musyawarah Desa". Musyawarah Desa yang dimaksud pada pasal tersebut membahas beberapa hal yang terkait dengan proses pendirian desa. Inti pokok bahasannya adalah; 1.) Pendirian BUMDes Desa sesuai dengan kondisi ekonomi dan sosial budaya mayarakat. 2.) Organisasi pengelola BUMDES. 3.) Modal Usaha BUMDES. 4.) Anggaran Dasar dan Anggaran Rumah Tangga BUMDES.

Empat Inti pokok bahasan inilah yang kemudian menjadi darsar pedoman bagi Pemerintah Desa dan Badan Permusyawaratan Desa untuk menetapkan Peraturan 
Desa tentang Pendirian BUMDes. Selanjutnya mengenai pengelolaan BUMDes, Permendesa No. 4/2015 mengatur secara jelas dan detail mengenai pengelolaan teknis pelaksanaan BUMDES disertai dengan peran dan fungsi dari masing-masing perangkat BUMDes, memang isi Permendesa No.4/2015 ini berlaku umum, artinya tetap saja dalam pelaksanaan di daerah harus ada penyesuaian yang kemudian diatur oleh peraturan Bupati/Walikota sesuai dengan keadaan alam, lingkungan, dan budaya setempat.

Pengelolaan BUMDes harus dikelola secara profesional dan mandiri sehingga diperlukan orangorang yang memiliki kompetensi untuk mengelolanya. Perekrutan pegawai ataupun manajer dan selevel harus disesuaikan dengan standar yang sudah ditetapkan dari AD/ART BUMDes. Sebagai sebuah lembaga yang juga diwajibkan mendapat profit, tentunya ada mekanisme yang harus ditaati oleh pengelola BUMDes dalam melakukan kerjasama dengan pihak lain. Misalnya kegiatan yang bersifat lintas desa perlu dilakukan koordinasi dan kerjasama antar pemerintah Desa dalam pemanfaatan sumber-sumber ekonomi, misalnya sumber air bagi air minum. Dalam melakukan Kerjasama dengan pihak ketiga oleh pengelola harus dengan konsultasi dan persetujuan Dewan Komisaris BUMDes. Dalam kegiatan harian pengelola harus mengacu pada tata aturan yang sudah disepkati bersama sebagaimana yang telah tertuang dalam AD/ART BUMDes, serta sesuai prinsip- prinsip tata kelola BUMDes.

Satu hal yang penting dalam pengelolaan BUMDes yakni dalam proses pengelolaan BUMDES amat dibutuhkan suatu pengelolaan dan pelaporan yang transparan bagi pemerintah dan masyarakat. Artinya dasar pengelolaan harus serba transparan dan terbuku sehingga ada mekanisme chek and balance baik oleh pemerintahan desa maupun masyarakat. Untuk langkah ke depan sangat diperlukan sebuah penyusunan rencana- rencana pengembangan usaha. Contoh yang dapat di ambil, untuk penjualan produk- produk yang dipengaruhi oleh musim, seperti penjualan pakaian, sandal, sepatu, dan sejenisnya penting untuk selalu memperhatikan perubahan mode, sebab jika tidak dilakukan besar kemungkinan produknya tidak diminati oleh pasar, untuk itu diperlukan inovasi baru atau selalu mewaspadai perubahan dan perkembangan yang terjadi di masyarakat.

\section{Pendirian dan Pengelolaan Badan Usaha Milik Desa (BUMDES) di Desa Pamulihan.}

Salah satu Desa yang termasuk dalam ciri khas, pendirian dan pengelolaan Badan Usaha Milik Desa yang telah diterangkan pada halaman sebelumnya, adalah Desa Pamulihan Kecamatan Cisurupan Kabupaten Garut, dimana desa ini merupakan desa yang sudah memiliki BUMDES dan telah berjalan mulai Tahun 2019. Pembentukan Badan Usaha Milik Desa (BUMDes) pada Desa Pamulihan bertujuan sebagai pendorong pembangunan ekonomi tingkat desa. Pembangunan Ekonomi pada Desa Pamulihan ini didasarkan keinginan desa untuk menjadikan masyarakatnya yang kreatif, inovatif, dan mampu 
meningkatkan keproduktivitas individu. Pembentukan BUMDes tersebut oleh masyarakat desa dilandasi oleh prinsip kooperatif, partisipatif, dan emansipatif masyarakat desa. Desa Pamulihan menjalankan BUMDes ini berpedoman pada Peraturan Daerah Kabupaten Garut Nomor 1 Tahun 2015 tentang Badan Usaha Milik Desa (BUMDes) yang mejadi acuan dalam pembentukan Badan Usaha Milik Desa yang ada di Kabupaten Garut.

Pengelolaan BUMDES harus dikelola secara professional dan mandiri, begitupula dengan BUMDes Desa Pamulihan menyeleksi orangorang yang memiliki kompetensi untuk mengelolanya. Dilihat kenyataan perekrutan Pengelolaan BUMDes ini berlangsung selektif. Menurut Kepala Desa Pamulihan "Kami melakukan seleksi dan pemilihan untuk mengelola BUMDes kami agar tujuan yang diinginkan dapat tercapai demi kesejahteraan masyarakat desa ini. Untuk Pengelola sendiri ada Ketua Bumdes Desa Pamulihan, dibantu oleh 4 Ketua unit usaha BUMDES, dan karyawan" setelah itu kepala desa pun memberikan informasi bahwa "Ketua BUMDES kami berasal dari Perusahaan Perkebunan PTPN VIII Subang yang telah senior dan pensiunan, dan kebutulan ketua bumdes nya ini dulu bergerak pada bagian LPD desa ini, jadi kami tidak sembarang memilih pengelola BUMDes ini."

Sementara itu pada penyeleksi karyawan bumdes ini adalah dari mayarakat yang memiliki latar belakang yang desa ini menginginkan adalah minimal SMP. Ini diharapkan mereka harus mampu menyusun laporan aktivitas BUMDes yang berkaitan dengan pekerjaannya. Contohnya pada Desa Pamulihan Unit jasa pedagangan pupuk dan bibit pertanian, mereka harus menyusun laporan barang-barang yang terjual dan sisa barang ditoko dan gudang setiap periode tertentu (per tri wulan (3 bulan) dan satu semester (6) bulan sekali).

Pengelolaan BUMDES di Desa Pamulihan ini juga melibatkan masyarakat untuk berperan aktif dalam pembangunan di desanya. Keterlibatan masyarakat ini dimulai dari perencanaan, pelaksanaan, hinggan pengelolaan dan evaluasi. Pengambilan keputusan dalam perencanaan pembangunan dilakukan dengan melibatkan stakeholder dalam masyarakat. Kepala Desa dan tokoh masyarakat Desa Pamulihan memegang peran penting untuk mendistribusikan ide, gagasan, manfaat pembangunan ini kepada warga sehingga muncul komitmen seluruh warga untuk terlibat dalam pengelolaan pembangunan sarana dan prasarana di Desa Pamulihan. Partisipasi masyarakat saat pelaksanaan pembangunan infrastruktur sarana dan prasarana Desa Pamulihan renovasi bangunan masjid dan kantor Desa Pamulihan tersebut melalui gotong royong di lingkungan RT mereka. Bentuk partisipasi mayarakat setelah perenovasian sudah bisa nikmati dan dimanfaatkan. 
6. Perkembangan

Peningkatan Perekonomian Desa Pamulihan dengan keberadaan Badan Usaha Milik Desa atau BUMDES.

Jauh sebelum adanya BUMDesdi Desa Pamulihan ini masyarakatnya masih sangat konsumtif. Masyarakat seakan bersaing satu sama lain untuk memenuhi keinginan dan gaya hidup yang seolah tidak ingin kalah antara yang satu dengan yang lainnya. Sehingga dengan kehidupan yang seperti itu semakin terlihat kesenjangan ekonomi yang semakin besar, karena kehidupan konsumtif yang tidak dibarengi dengan pendapatan yang memadai. Desa Pamulihan ini termasuk desa dengan ekonomi yang kurang stabil karena tidak ada perkembangan yang terlihat signifikan dari usahausaha yang didirikan, mata pencaharian masyarakatnya yang cenderung monoton yaitu dari pertanian, selain itu kondisi masyarakat konsumtif yang tidak ada keinginan melakukan perubahan juga menjadi pemicu utama ketidak stabilan perekonomian masyarakat.

Dari sekian banyak masyarakat yang konsumtif tentunya ada segelintir masyarakat yang memiliki kesadaran dan ingin mengubah hidupnya. Tak sedikit juga dari mereka yang ingin mulai membangun usaha, akan tetapi pada saat itu hanya LPD yang menjadi tempat masyarakat dalam mengambil kredit. Seperti yang telah diketahui berdasarkan survei yang telah dilakukan bahwa bunga yang diberikan LPD untuk kredit lumayan besar sehingga masyarakat masih berpikir ulang untuk meminjam kredit sebagai modal usaha. Jadi, dapat disimpulkan bahwa sebelum adanya BUMDes di Desa Pamulihan perekonomiannya tidak stabil karena masyarakat yang bersifat konsumtif yang belum memiliki keinginan untuk merubah gaya hidup mereka. Selain itu pemicu ketidakstabilan perekonomian di desa ini adalah keinginan masyarakat yang muncul akan tetapi terbentur dengan keadaan kredit yang mempunyai bunga lumayan tinggi.

BUMDes Desa Pamulihan yang memiliki tujuan meningkatkan perekonomian desa telah mampu memberikan dampak yang sangat positif terhadap perekonomian Desa Pamulihan. Masyarakat Desa Pamulihan yang mayoritas merupakan masyarakat kelas menengah kebawah mendapatkan kesempatan untuk mulai memutar roda perekonomian dengan adanya BUMDes di Desa Pamulihan itu sendiri. BUMDes yang merupakan program pemerintah untuk mengembangkan perekonomian terutama di perekonomian desa dapat mendorong perkembangan perekonomian desa dengan cara memberikan pinjaman dana bagi masyarakat kecil yang akan membuat usaha dengan bunga yang sangat minim. Bunga yang minim diterapkan dengan tujuan untuk mendorong masyarakat kelas kebawah tersebut untuk memulai usaha dan dapat meningkatkan taraf hidup masyarakat desa. Bunga minim juga diharapkan dapat membantu berbagai usaha yang ditekuni masyarakat Desa Pamulihan agar lebih beragam.

Mereka meminjam uang di bumdes di karenakan bunga yang dikenakan atas pinjaman tersebut sangat minim dibandingkan dengan 
LPD di desa itu sendiri. Namun dana yang dipinjam tentunya tidak akan sebesar dana yang bisa di peroleh ketika meminjam di LPD. Bagi sebagian masyarakat yang mampu membaca peluang bisnis. Mereka meminjam dana di bumdes dan melakukan usaha jual beli pupuk kotoran ayam, pupuk urea, ZA/TS, pupuk kandang, bibit tanaman pertanian, warung SEMBAKO, warung makanan dan perdagangan lainnya selain pertanian yang menjadi mata pencaharian pokok masyarakat Desa Pamulihan.

Sekarang BUMDES Desa Pamulihan berencana untuk membuat Pertashop yaitu program usaha kerja sama antara PT. Pertamina (Persero) dengan Kemendagri dengan mendirikan Pertamini, minimarket dan grosir sembako dilokasi tanah milik desa dengan menggandeng pihak ke tiga untuk investasi dengan perjanjian bagi hasil antara pemodal/investor dan Bumdes selaku pemilik tanah.

Kondisi Desa Pamulihan yang jauh dari pusat kota dan jauh dari SPBU dengan jarak $10 \mathrm{Km}$, berpeluang besar memikat konsumen masyarakat pemilik kendaraan roda dua dan roda empat serta warung-warung rumahan yang akan menjadi konsumen di area Pertashop BUMDes Desa Pamulihan.

Konsumen dan warungwarung rumahan atau toko kecil agar nantinya warung-warung dan toko kecil tersebut dapat mengambil barang dagangan di toko grosir dan minimarket yang akan dibuat oleh BUMDes Desa Pamulihan, sehingga itu akan menambah pendapatan omset dan keuntungan BUMDes, selain mempermudah akses masyarakat yang membuka warung- warung/ toko kecil tersebut dalam memperoleh barang dagangannya.

Setelah diterapkannya BUMDes di Desa Pamulihan dan melihat partisipasi masyarakat yang begitu tinggi, banyak dampak positif yang diberikan kepada perekonomian masyarakat desa. Pembangunan di desa semakin meningkat. BUMDes di Desa Pamulihan ini dinilai sudah berhasil dijalankan peran mendorong pertumbuhan ekonomi desa, meskipun belum semua unit berjalan efektif. Keberhasilan ini tentunya tidak luput dari kerja keras dan partisipasi seluruh masyarakat desa. Dengan memanfaatkan BUMDes, kondisi masyarakatyang dulunya dikatakan "Kurang Mampu" sekarang kehidupannya lebih baik, kesejahteraan meningkat, pengangguran berkurang, dan sedikit banyak pembangunan yang dilakukan berorientasi pada masyarakat.

Suatu kebijakan akan menimbulkan suatu dampak. Dampak kebijakan public merupakan sebuah studi evaluasi terhadap suatu kebijakan pemerintah yang sudah diimplementasikan kepada sasaran kebijakan. Untuk mengetahui dampak perlu adanya evaluasi. Evaluasi dampak dalam penelitian ini menggunakan jenis studi evaluasi yang dikemukakan oleh Finsterbuch dan Motz (dalam wibawa, 1994:74) yaitu menggunakan single program before after. Dimana evaluator hanya menggunakan kelompok eksperimen yaitu kelompok yang dikenai kebijakan untuk memperoleh data dari evaluasi dampak kebijakan ini. Kelompok yang dikenai kebijakan disini adalah masyarakat Desa Pamulihan. Dalam 
menggunakan jenis evaluasi single program before after ini untuk memperoleh data mengenai keadaaan masyarakat sebelum dan setelah adanya BUMDes.

\section{Kesimpulan}

Berdasarkan pemaparan diatas, simpulan yang didapat sebagai berikut, Pertama, BUMDes Desa Pamulihan telah berhasil memberi dampak yang positif bagi peningkatan perekonomian desa dan kesejahteraan masyarakat, BUMDES Desa Pamulihan yang berdampak terhadap tingkat masyarakat konsumtif ini, semakin berkurang, dan masyarakat produktif mulai meningkat. Pengangguran pada desa Pamulihan ikut berkurang karena masyarakat yang mulai kreatif untuk membuat taraf hidupnya menjadi lebih baik dengan usaha-usaha kecil yang masyarakat desa setempat dirikan. Pembangunan desa pun semakin lancar dengan adanya dana yang dihasilkan dari BUMDes; Kedua, Pengelolaan BUMDes sangat tertata dengan berpacu pada peraturan yang sudah ditetapkan oleh Pemerintah. Pengelolaan BUMDes ini dilihat dari pengurus BUMDes, yang sebelumnya di seleksi dan memilih secara ketat orang yang bisa mengelola BUMDes ini dengan baik dan mampu mengubah pemikiran masyarakat desa setempat.

Ketiga, BUMDes Desa Pamulihan walaupun belum maksimal dalam menjalankan unit-unit usahanya. Dari keempat unit usaha BUMDes baru dua yang telah berjalan dengan efektif, usaha tersebut adalah simpan pinjam, dan usaha perdagangan pupuk kandang, UREA, ZA/TSP, Insektisida dan bibit tanaman jati. Hal tersebut disebabkan karena sumber daya manusia yang belum mahir dalam mengolah unit-unit tersebut tetapi adanya tingkat partisipasi masyarakat yang begitu tinggi terhadap kegiatan BUMDes yang sudah berjalan membuat BUMDES Desa Pamulihan dapat menunjang ekonomi masyarakat desa.

Berdasarkan pemaparan di atas, saran yang dapat diberikan adalah bagi pemerintah desa dan pengelola BUMDes agar lebih cepat membuka usaha-usaha baru seperti Pertashop, Grosir sembako dan Minimarket, agar tujuan BUMDes memaksimalkan kesejahteraan masyarakat desa setempat. Sedangkan bagi pemerintah Kabupaten dan Pusat agar melakukan control berkala dan membantu peningkatan SDM secara berkala pula untuk keamjuan BUMDes. Dengan membantu control secara berkala BUMDes Desa Pamulihan berjalan secara efektif, efisien, bersih serta profitable, agar dikemudian hari apabila BUMDes terjadi permasalahan bisa teratasi dan menemukan jalan supaya lancar kembali. Pemerintah juga bisa melihat dampak dari pendirian BUMDes ini yang tetap mengacu pada kesejahteraan masyarakat desa. Karena kebijakan publik yang seperti inilah yang harus diterapkan pada tingkat desa.

\section{Referensi}

Amri, K. (2019). Bumdes Acceleration Towards Mandiri Village. Iapa Proceedings Conference. https://doi.org/10.30589/proce edings.2019.236

Faedlulloh, D. (2018). BUMDes dan Kepemilikan Warga: Membangun Skema Organisasi Partisipatoris. Journal of Governance, 3(1). https://doi.org/10.31506/jog.v3 


\section{i1.3035}

Tanjung, I. (2013). Kearifan Lokal dan Pemberantasan Korupsi dalam Birokrasi. MIMBAR, Jurnal Sosial Dan Pembangunan, 29(1). https://doi.org/10.29313/mimb ar.v29i1.375

Tokan, F. B. (2016). Modal Sosial Kajian Tentang Tata Kelola Pembangunan Masyarakat Desa Melalui Gemohing Di Kecamatan Witihama - Kabupaten Flores Timur. JOURNAL OF GOVERNMENT (Kajian Manajemen Pemerintahan Dan Otonomi Daerah), 1(2), 46-80.

Widiastuti, H., Putra, W. M., Utami, E. R., \& Suryanto, R. (2019). Menakar tata kelola badan usaha milik desa di Indonesia. Jurnal Ekonomi Dan Bisnis, 22(2). https://doi.org/10.24914/jeb.v2 2i 2.2410

[PKDSP] Pusat Kajian Dinamika Sistem Pembangunan. 2007. Buku Panduan Pendirian dan Pengelolaan Badan Usaha

Milik Desa (BUMDES). Malang (ID). PKDSP

[UU] -----2014. Undang-Undang Nomor 06 Tahun 2014 Tentang Desa. Jakarta (ID): UU NKRI

Putra AS. 2015. Badan Usaha Milik Desa : Sprit Usaha Kolektif Desa. Jakarta (ID) : Kementrian Desa, Pembangunan Daerah Tertinggal dan Transmigrasi RI.

Ramadana CB, Ribawanto $\mathrm{H}$, Suwondo. 2013. Keberadaan Badan Usaha Milik Desa Sebagai Penguatan Ekonomi Desa. JAP [internet]. [diunduh 2016 okt 03]; 1(6):1068-1076. Tersedia pada : http:// administrasipublik.studentjourna l.ub.ac.id/ index.php/jap/article/view/ 189. Akuntansi UPG Bali, 2018,
Keberadaan Badan Usaha Milik Desa (BUMDes) Sebagai Penguatan Ekonomi desa Abiantuwung.

Indonesia Abstrak Risadi AA. 2012. BUMDes. Jakarta (ID) : Dapur index.php/jap/article/view/ 189. Risadi AA. 2012. BUMDes. Jakarta Suroso H, Hakim A, Noor I. 2014. Faktor-Faktor yang Mempengaruhi Partisipasi Masyarakat dalam Perencanaan Pembangunan di Desa Banjaran Kecamatan Driyorejo Kabupaten Gresik.JW. [internet]. [Diunduh 2017 Feb 17]; 17(1) : Tersedia pada : http://wacana. ub.ac.id/index.php/wacana/artic le/view/29 0

Zulifah Chikmawati, 2019, Peran Bumdes Dalam

www.balipos.com Surya Dharma, Pinondang Simanjuntak.2002. Paradigma Birokrasi Pemerintahdan Otonomi Daerah. Jurnal Bisnis dan Birokrasi

Peraturan Daerah Kabupaten G a r u t Nomor 1 Tahun 2015 tentang Badan Usaha Milik Desa

------Lembaran Negara, UU No. 22 Tahun 99 Tentang Pemerintahan Daerah

------Lembaran Negara, UU No. 23 Tahun $2004 \quad$ Tentang Pemerintahan Daerah

------Lembaran Negara, UU. No. 32 Tahun $2014 \quad$ Tentang Pemerintahan Daerah. 